\title{
Water relations of climbing ivy in a temperate forest
}

\section{Journal Article}

Author(s):

Leuzinger, S.; Hartmann, A.; Koerner, C.

Publication date:

2011-06

Permanent link:

https://doi.org/10.3929/ethz-b-000037717

Rights / license:

In Copyright - Non-Commercial Use Permitted

Originally published in:

Planta 233(6), https://doi.org/10.1007/s00425-011-1363-6 


\title{
Water relations of climbing ivy in a temperate forest
}

\author{
S. Leuzinger $\cdot$ A. Hartmann $\cdot$ C. Körner
}

Received: 13 August 2010/Accepted: 12 January 2011/Published online: 4 February 2011

(C) Springer-Verlag 2011

\begin{abstract}
Ivy (Hedera helix) is the most important liana in temperate European forests. We studied water relations of adult ivy in a natural, $35 \mathrm{~m}$ tall mixed deciduous forest in Switzerland using a construction crane to access the canopy. Predawn leaf water potential at the top of climbing ivy ranged from -0.4 to $-0.6 \mathrm{MPa}$, daily minima ranged from -1.3 to $-1.7 \mathrm{MPa}$. Leaf water potentials as well as relative sap flow were held surprisingly constant throughout different weather conditions, suggesting a tendency to isohydric behaviour. Maximum stomatal conductance was $200 \mathrm{mmol} \mathrm{m}^{-2} \mathrm{~s}^{-1}$. The use of a potometer experiment allowed us to measure absolute transpiration rates integrated over a whole plant of $0.23 \mathrm{mmol} \mathrm{m}^{-2} \mathrm{~s}^{-1}$. Nightly sap flow of ivy during warm, dry nights accounted for up to $20 \%$ of the seasonal maximum. Maximum sap flow rates were reached at ca. $0.5 \mathrm{kPa}$ vpd. On the other hand, the host trees showed a less conservative stomatal regulation, maximum sap flow rates were reached at vpd values of ca. $1 \mathrm{kPa}$. Sap flow rates of ivy decreased by ca. $20 \%$ in spring after bud break of trees, suggesting that ivy profits strongly from warm sunny days in early spring before budbreak of the host trees and from mild winter days. This species may
\end{abstract}

S. Leuzinger $(\square)$

Forest Ecology, Department of Terrestrial Ecosystems, ETH Zürich, Universitätsstr.16, 8092 Zurich, Switzerland e-mail: Sebastian.Leuzinger@env.ethz.ch

\author{
A. Hartmann \\ Institute of Agricultural Sciences, ETH Zürich, \\ Universitätsstr. 2, 8092 Zurich, Switzerland \\ C. Körner \\ Institute of Botany, University of Basel, \\ Schönbeinstrasse 6, 4056 Basel, Switzerland
}

benefit from rising winter temperatures in Europe and thus become a stronger competitor against its host trees.

Keywords Global warming - Granier method . Hedera $\cdot$ Lianas - Sap flow - Stomatal conductance . Leaf water potential
Abbreviations
A Sap wood area
b Reference conductance at $1 \mathrm{kPa}$
$g_{\text {s }} \quad$ Stomatal conductance
$g_{\mathrm{c}} \quad$ Canopy conductance
m Vpd sensitivity
PAR Photosynthetically active radiation
SF Sap flow
vpd Vapour pressure deficit
WSD Water saturation deficit
$\alpha \quad$ Fitting parameters for the non-linear fit between SF and vpd
$\beta \quad$ Fitting parameters for the non-linear fit between
SF and vpd
$\psi \quad$ Leaf water potential

\section{Introduction}

Lianas contribute greatly to forest biodiversity and affect many aspects of forest dynamics. Lianas compete with their host trees for resources like light, water, nutrition and space, and it has been shown that they may be particularly successful in open, disturbed forests (Zhu and Cao 2010). By using their host as a climbing frame, they save resources that otherwise would have to be invested in massive stems and roots (Putz and Holbrook 1991). 
The weight of lianas and the additional leaf area exposed to wind can enhance forest dynamics, particularly through wind throw (Clark and Clark 1990; Schnitzer and Bongers 2002; Schnitzler and Heuzé 2006). Once lianas have reached the top of their host tree crown, they often suppress tree growth and regeneration (Putz 1984). In the case of Ivy (Hedera helix L.), the most abundant liana in temperate forests of Europe (and a key invader in North America, e.g. Biggerstaff and Beck 2007; Ringold et al. 2008), many of the adverse influences on trees attributed to lianas do not apply. Ivy is neither particularly aggressive, nor does it overgrow healthy tree crowns, but usually remains in the subcanopy (Mitchell 1975). Its distribution in Europe is limited to the north and east by the $-25^{\circ} \mathrm{C}$ minimum isotherme (Iversen 1944; Parker 1962; Andergassen and Bauer 2002). The largest individuals show diameters $>25 \mathrm{~cm}$ and can be over 60 years old (Heuzé et al. 2009).

Ivy is quite robust and able to cope with many different light, temperature and water regimes, with a strong potential of phenotypic adaptation (see Metcalfe 2005). A single tree often hosts various clones of ivy, intermingled and physically connected (anastomosis). Massive evergreen canopies up to $30 \mathrm{~m}$ above ground are often maintained by only a few thin stems, and severing some of them does not harm the plant as long as a single vine links to the ground (personal observation). This means that the water conducting tissue must be extremely efficient (low Huber value, i.e. cross-sectional xylem area to supplied leaf area) and able to avoid cavitation. In contrast, ivy has intermediate maximum leaf conductance $\left(113 \mathrm{mmol} \mathrm{m}^{-2} \mathrm{~s}^{-1}\right)$ and low transpiration rates $\left(1.0 \mathrm{mmol} \mathrm{m}^{-2} \mathrm{~s}^{-1}\right.$, Carter and Teramura 1988). Elias (1979) also reports low transpiration rates combined with low maximum water saturation deficit (WSD) and high water holding capacity for H. helix. Apart from the cited literature on data mostly from small or potted plants, little information is available on the ecology of $H$. helix in situ, and there is a striking gap in our knowledge of in situ water relations, partly due to difficult crown access of adult individuals.

Because ivy relies on the host tree to provide structural support, it is not only able to conduct water very efficiently, but it also saves in structural tissue, allowing it to grow fast. Recent studies suggest that lianas take exceptional advantage from atmospheric $\mathrm{CO}_{2}$ enrichment during their juvenile life stage in deep shade (Granados and Körner 2002) and therefore may become more competitive (Körner 2004; Mohan et al. 2006). This is also true for ivy both in the juvenile and adult stages (Hättenschwiler and Körner 2000, 2003; Zotz et al. 2006). Fischer and Feller (1994) have further shown that photosynthetic proteins in ivy are conserved throughout winter and are activated rapidly during warm spells. Therefore, ivy may additionally profit from milder winters when light availability is ample in deciduous forests. This hypothesis is supported by a recent dendrochronological study on ivy (Heuzé et al. 2009), which reports increased growth rates during years with exceptionally warm winters.

The aim of this study was threefold. (1) We wanted to fill in a gap in fundamental knowledge on in situ water relations of mature ivy. (2) We systematically compared ivy water relations with water relations of host trees before and after tree leafing to test the hypotheses that ivy takes advantage of warm, sunny winter days. (3) We assessed the possibility of using Granier-type heat-dissipation probes in ivy, and suggested a calibration for their use in this species. To achieve these goals, we used standard methods for monitoring water relations (sap flow and leaf water potential measurements, porometry, and a potometer approach) and the Swiss canopy crane (SCC) to provide access to the upper canopy.

\section{Materials and methods}

\section{Site description}

The experiment was located at the SCC research site in a diverse mixed deciduous forest on a gentle north slope about $12 \mathrm{~km}$ south of Basel, Switzerland $\left(47^{\circ} 28^{\prime} \mathrm{N}, 7^{\circ} 30^{\prime} \mathrm{E}\right.$, elevation: $550 \mathrm{~m}$ a.s.1.). The forest is approximately 100 years old with tree heights between 30 and $38 \mathrm{~m}$. Stem density (diameter at breast height $\geq 10 \mathrm{~cm}$ ) in the stand is ca. 415 trees $\mathrm{ha}^{-1}$. The stand has a total basal area of $46 \mathrm{~m}^{2} \mathrm{ha}^{-1}$, a leaf area index of ca. $5 \mathrm{~m}^{2} \mathrm{~m}^{-2}$ in the experimental area and is dominated by Fagus sylvatica $\mathrm{L}$. and Quercus petraea (Matt.) Liebl. Also present as companion species are Carpinus betulus L., Tilia platyphyllos Scop., Acer campestre L. and Prunus avium L.. Furthermore, there is a strong presence of conifers (Abies alba Mill., Picea abies L., Pinus sylvestris L. and Larix decidua Mill.). The understory is dominated by Lonicera xylosteum, Corylus avellena and Daphne laureola as well as young trees (especially Acer pseudoplatanus, Fraxinus excelsior and Fagus sylvatica). Ivy (Hedera helix L.) plays a prominent role on the forest floor (juvenile life phase) as well as in the canopy. With stems up to $15 \mathrm{~cm}$ diameter at breast height, ivy reaches over $25 \mathrm{~m}$ in height in some trees and occupies a significant fraction of the forest's sub-canopy. Nearly all Larix and Picea trees and most of Quercus and Carpinus trees at this site host large ivy individuals.

The climate is a typical humid temperate zone climate with mild winters and moderately warm summers. The mean temperatures during January and July are 2.1 and $19.1^{\circ} \mathrm{C}$, respectively. The long-term total annual precipitation for the region averages $990 \mathrm{~mm}$, of which two-thirds fall during the growing season ranging from the end of April 
until the end of October. The soil is a silty-loamy rendzina on calcareous bedrock with a pH of 5.8 in the top $10 \mathrm{~cm}$ of soil profile. The accessible profile depth is ca. $30 \mathrm{~cm}$.

Plant material and canopy access

A 45-m tower crane with a gondola on a 30-m jib provided access to tree canopies over an area of $2,800 \mathrm{~m}^{2}$. The experimental design (see below) required access to individuals of Hedera helix at two measuring heights (upper and lower canopy; 12 and $23 \mathrm{~m}$ height above ground). Therefore, appropriate host trees infested with adult Hedera helix reaching at least $23 \mathrm{~m}$ in height were selected. The multiple infestations of host trees with different stems of Hedera helix and the countless intersections of stems and branches prevented the identification of single individuals over the whole height gradient. Therefore, it was not possible to ensure that readings on the two measuring heights were always taken from the same genet. Readings of leaf conductance, light exposure and leaf water potential (see below) were taken from 'individuals' of Hedera helix on six different host trees (two Larix decidua, one Picea abies and three Quercus petraea individuals).

\section{Environmental data}

Wind speed, photon flux density, rainfall, air temperature and relative humidity were measured above the tree canopy using a weather station located at the top of the crane (anemometer AN1, quantum sensor QS, tipping bucket rain gauge RG1, shielded temperature and relative humidity probe RHA 1, Delta-T Devices Ltd., Cambridge, UK). A self-made wet and dry bulb aspiration psychrometer attached to the crane mast at ca. $30 \mathrm{~m}$ was used to calculate vapour pressure deficit (vpd) at canopy height. All data were recorded as 10 min means with a data logger (DL2e, Delta-T Devices Ltd.). Soil water content was obtained from hourly measurements of seven theta-probes (ML2x, Delta-T Devices Ltd.) connected to another data logger (DL2e, Delta-T Devices Ltd.).

Leaf conductance, photon flux density and leaf water potential measurements

Measurements were taken during five clear, sunny days from May to September 2004 (12 May, 10 June, 22 July, 2 August and 2 September) from mature leaves of different branches of the current year. Leaf conductance $\left(g_{\mathrm{s}}\right)$ was measured with a portable diffusion-porometer (AP4, Delta-T Devices Ltd.) and data were recorded as soon as the readings were constant. Photosynthetically active radiation (PAR) was measured in the direction vertical to leaf blade orientation using a photodiode integrated in the measuring unit of the diffusion-porometer. Following each porometer measurement, leaf water potential $(\Psi)$ of the same leaf was recorded using a pressure chamber (SKMP 1400, Sky Instruments, Powys, UK). To prevent water loss after cutting the leaf, samples were wrapped with sticky tape and measured immediately after cutting them off.

Daily courses of $g_{\mathrm{s}}$ and $\Psi$ in adult ivy were measured at 12 and $23 \mathrm{~m}$ above the ground. For a single time slot, three to four readings of leaf conductance, light exposure and leaf water potential were taken at both heights, which took ca. 2 times $15 \mathrm{~min}$. In order to eliminate diurnal bias, measurements at both heights were repeated immediately in opposite order. These four data sets (two for each height) were then pooled and averaged to represent the mean for a certain time of day with similar environmental conditions. This procedure was repeated for other individuals in random order. For the comparison between ivy and host trees, the data set of Keel et al. (2007) on stomatal conductance of trees in the same area (both host trees and surrounding trees) were used. The values shown represent means of measurements on bright days with similar soil moisture status and history from all six deciduous species present in the area (see above, for details see Keel et al. 2007).

We modelled the vpd $-g_{\mathrm{s}}$ relationship using the model that was favoured in a comparison study of several models (Oren et al. 1999):

$g_{\mathrm{s}}=-\mathrm{m} \cdot \ln (\mathrm{vpd})+b$, where $\mathrm{m}$ represents the vpdsensitivity and $b$ is the reference conductance at $1 \mathrm{kPa}$.

\section{Sap flow measurements}

The constant heat-flow technique described by Granier (1985) was used to measure the sap flow in the xylem. Each sensor (UP, Kolkwitz, Germany) consisted of two $20 \mathrm{~mm}$ long, $2 \mathrm{~mm}$ diameter probes. Each probe was equipped with a copper-constantan thermocouple and wrapped with a heating wire. The two probes were inserted in radial holes in the sapwood at breast height (holes lined with a thin aluminium tube).

Sap flow readings were recorded between 1 April and 25 September in 2004 on six mature 'individuals' of Hedera helix as well as on 9 trees (three Quercus petraea, three Fagus sylvatica and three Carpinus betulus individuals.). To protect sap flow sensors from rain and atmospheric thermal fluctuations, each sensor pair was covered with an aluminium box filled with polyester wool. Readings were taken at 30-s intervals and recorded as 10-min means with a data logger (DL2e, Delta-T Devices Ltd.). Because nightly minimum sap flow rates were approximately constant, no trend removal was necessary.

We used relative sap flow values (seasonal maximum set to 1 , not occurring during the shown periods), because the sapwood of Hedera helix remains active for many years and 
even central parts of the stem can support sap flow. Thus, the 20-mm-long probes did not capture the complete cross-sectional sap flow in any stem exceeding a diameter of $4 \mathrm{~cm}$ (plus phloem layer). Furthermore, Hedera helix produces a multitude of interconnected stems (anastomosis), making it impossible to infer absolute flow per unit leaf area. Accordingly, we could not calculate absolute whole-canopy conductance, but rather estimated relative canopy conductance $\left(g_{\mathrm{c}}\right)$ by dividing the 95 th percentile relative sap flow values of each vpd class by the corresponding vpd value. This represents a unit-less form of the inverted Penman-Monteith equation applied for example in Pataki et al. (1998). This allowed us to fit the same model to sap flow data as to the stomatal conductance data, and compare $e^{\mathrm{b} / \mathrm{m}}$, the (hypothetical) value of complete stomatal closure (Monteith 1995). A non-linear model used for photosynthesis-light curves was fitted to the 95th percentile sap flow (SF)-vpd curves: $\mathrm{SF}_{95 \text { th }}$ percentile $=\mathrm{SF}_{\max } \times(1-\exp (-\alpha \times \mathrm{vpd} /$ $\left.\left.\mathrm{SF}_{\max }\right)\right)-\beta$ with $\alpha$ and $\beta$ parameters to be fitted. Vapour pressure deficit values were binned in $0.1 \mathrm{kPa}$ classes.

\section{Potometer experiment}

In an attempt to determine absolute transpiration per unit leaf area, we constructed an in situ potometer experiment. The experiment also allowed us to calibrate the Granier sap flow sensors for ivy. We selected an individual that had only one climbing stem (ca. $24.5 \mathrm{~m}$ total plant height), which was cut off under distilled and degassed water (in order to prevent embolism) ca. $0.5 \mathrm{~m}$ under the two inserted sap flow sensors. Water consumption was then monitored (10 min intervals) by refilling a glass cylinder from which the stem drew water. Nocturnal water supply was ascertained by connecting the cylinder with a second, larger water reservoir. Total nocturnal water consumption was then measured the next morning and all following readings were taken in intervals of $10 \mathrm{~min}$ as before. The colouring of the water at the end of the experiment showed that the whole stem xylem area $\left(14.6 \mathrm{~cm}^{2}\right.$ at breast height) conducted water and supplied a total leaf area of $54 \mathrm{~m}^{2}$ ( sap wood to leaf area ratio $=2.8 \times 10^{-5} \mathrm{~m}^{2} \mathrm{~m}^{-2}$ ). At the end of this experiment, we harvested all leaves in height intervals of $5 \mathrm{~m}$. For each interval, we took five subsamples of $10-60 \mathrm{~g}$ to measure leaf weight and leaf area (LI-3100 AreaMeter, LI-COR, Lincoln, NK, USA) in order to calculate the specific leaf area (SLA). The leaf area index (LAI) of this individual was about 10 if we refer to the estimated projected area of all shoots at ground level.

\section{Data analysis}

The free software package ' $\mathrm{R}$ ' (version 2.10.1, R Development Core Team 2009) was used to fit the non-linear models (package nlme, generalised least squares model, function 'gnls'). All graphics were drawn using R.

\section{Results}

General characterisation of water use in Hedera helix

During the five measuring days, mean predawn leaf water potentials $(\Psi)$ ranged form about -0.33 to about $-0.48 \mathrm{MPa}$ in $12 \mathrm{~m}$ height above ground, and from about -0.43 to about $-0.63 \mathrm{MPa}$ in $23 \mathrm{~m}$ height above ground (Fig. 1). Soil moisture was moderate to high during all five measuring days with soil water content never falling below $29 \%$ vol. When accounting for the $0.11 \mathrm{MPa}$ difference in hydrostatic pressure the readings between the two sampling heights did not differ significantly ( $t$ test, $n=6, P=0.50$ ). Diurnal courses in leaf water potential $(\Psi)$ showed values from -1.1 to $-1.4 \mathrm{MPa}$ at $12 \mathrm{~m}$ height above ground, and from -1.3 to $-1.7 \mathrm{MPa}$ in $23 \mathrm{~m}$ height. Leaf water potential dropped faster during the day at $23 \mathrm{~m}$ than at $12 \mathrm{~m}$ above ground, and differences of daily minimum $\Psi$ between heights were larger than expected from the hydrostatic difference alone (Fig. 1).

The diurnal course of leaf conductance was highly variable both within and between measuring heights (Fig. 1). Most leaves were at least partly shaded; therefore, these values do no represent physiological maxima. Light conditions at the studied leaves varied a lot, with a median of $37 \mu \mathrm{mol} \mathrm{m} \mathrm{m}^{-2} \mathrm{~s}^{-1}$ at $12 \mathrm{~m}$ and $45 \mu \mathrm{mol} \mathrm{m} \mathrm{m}^{-2} \mathrm{~s}^{-1}$ at $23 \mathrm{~m}$ (between 9 and $18 \mathrm{~h}$ ). There was no significant difference in mean maximum leaf conductance at the two measuring heights ( $t$ test, $n=6, P=0.11$ ).

The daily amplitudes of relative sap flow density remained more or less unaffected throughout very different vpd conditions (Fig. 1). Overcast, cool weather conditions yielded similarly high sap flow rates than bright days. Relative sap flow reached $50 \%$ of the seasonal maximum even during days when vpd did not exceed $0.33 \mathrm{kPa}$. Out of 166 days of continuous sap flow data, only 14 days had a mean maximum relative sap flow below $50 \%$ of the seasonal maximum. In contrast to ivy, the amplitude of relative sap flow of trees was very responsive to changing weather conditions (data not shown).

Comparison between water relations of ivy and host trees

Stomata of ivy responded very sensitively to vapour pressure deficit, resulting in a strong down-regulation of leaf conductance and hence sap flow, as vpd exceeded ca. $0.5 \mathrm{kPa}$ (Intersection of linear fit through first six 95th percentiles of vpd classes with the maximum, dashed 


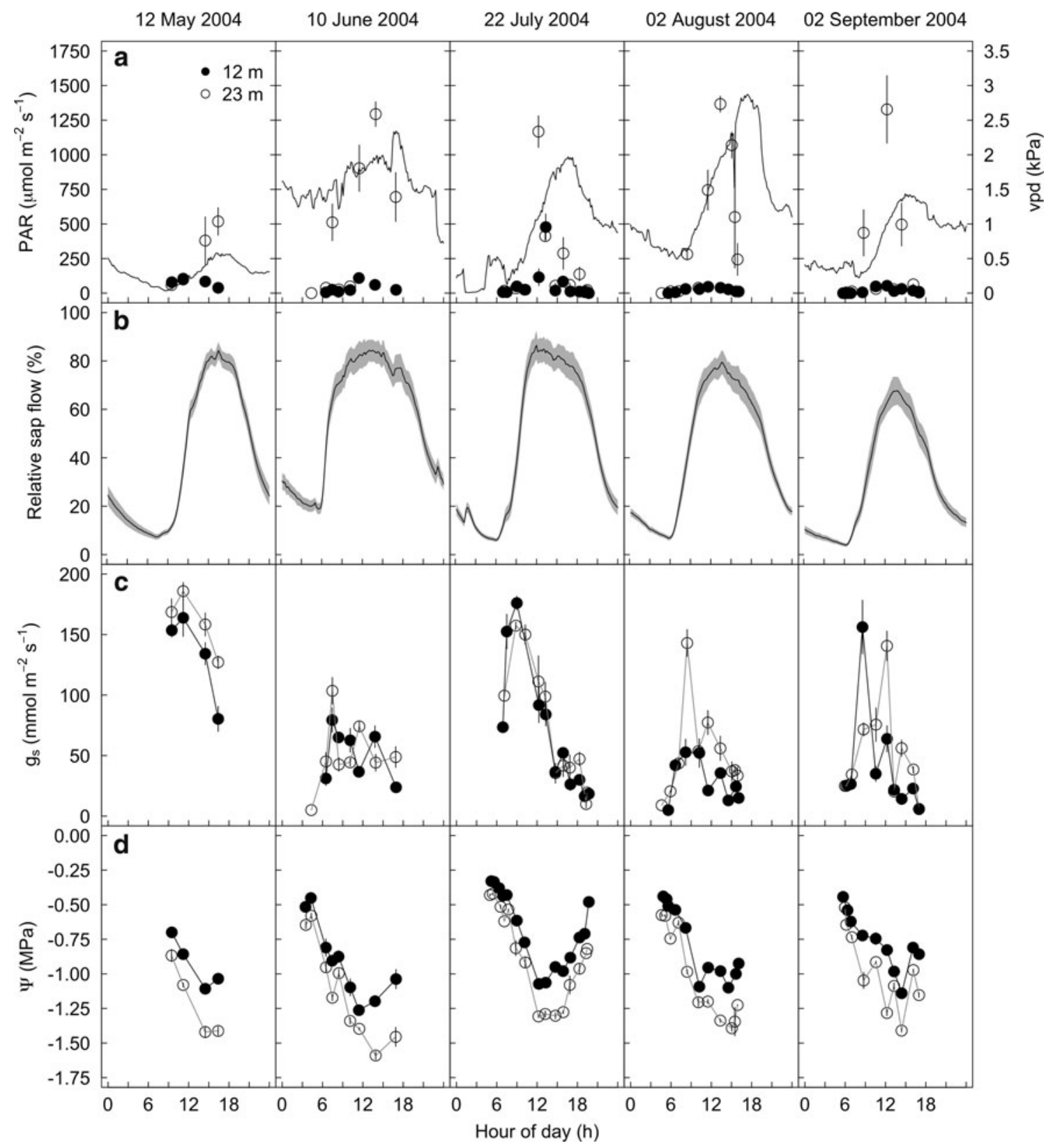

Fig. 1 Diurnal course of a light conditions at the leaves (PAR) and vapour pressure deficit (vpd, solid line), b mean sap flow (relative to seasonal maxima not shown here, $n=6$, grey area indicates one standard error of standardised series), c stomatal leaf conductance $\left(g_{\mathrm{s}}\right)$ and $\mathbf{d}$ leaf water potential $(\Psi)$ of Hedera helix. Open circles are data measured at $23 \mathrm{~m}$ above ground, filled circles are data measured at $12 \mathrm{~m}$ above ground. Error bars represent one standard error vertical line in left top panel of Fig. 2). Trees were less conservative and stomatal downregulation started at ca. $0.8 \mathrm{kPa}$ (vertical dashed line in right top panel of Fig. 2). The conservative water use of ivy compared with that of trees is also illustrated by fitting the model $g_{\mathrm{c}}=$ $-\mathrm{m} \ln (\mathrm{vpd})+b\left(g_{\mathrm{c}}=\right.$ relative canopy conductance computed from sap flow, top panels of Fig. 2) and $g_{\mathrm{s}}=$ $-\mathrm{m} \ln (\mathrm{vpd})+\mathrm{b}$ (for direct stomatal conductance measurements, bottom panels of Fig 2). The hypothetical vpd value at which $g_{\mathrm{c}}$ or $g_{\mathrm{s}}$ is zero $\left(e^{\mathrm{b} / \mathrm{m}}\right)$ is 2.7 versus $5.9 \mathrm{kPa}$ in ivy and trees, respectively $\left(g_{\mathrm{c}}\right)$, and 9.6 versus $18.1 \mathrm{kPa}$ in ivy and trees, respectively $\left(g_{\mathrm{s}}\right)$. Ivy thus showed a much higher vpd-sensitivity than the host trees.

Canopy greening during the last week of April strongly influenced water relations of ivy despite consistently high soil moisture. Daily maxima of relative sap flow were ca. $50 \%$ higher at vpd $<0.3 \mathrm{kPa}$ and up to $20 \%$ higher at vpd $>0.3 \mathrm{kPa}$ before than after the canopy leafing (Fig. 3). 
Relative sap flow of ivy was the highest of the whole season shortly before canopy closure. Maximum relative sap flow was reached at much lower vpd before than after the canopy leafing (Fig. 3).

\section{Potometer experiment}

Immediately after separating the stem from its below ground supplies, sap flow rate rose abruptly (presumably as a result of the instantly reduced hydraulic resistance), leading to a relaxation in stem water potential (partial refilling of parenchymal stem water storage). Disregarding this initial peak, maximum water consumption of the whole plant was $13.5 \mathrm{ml} \mathrm{min}^{-1}$ (i.e. $1.5 \times 10^{-4} \mathrm{~m}^{3} \mathrm{~m}^{-2} \mathrm{~s}^{-1}$ sap flow density with $14.6 \mathrm{~cm}^{2}$ sap wood area), corresponding to a mean transpiration rate of $0.23 \mathrm{mmol} \mathrm{m}^{-2} \mathrm{~s}^{-1}$ (per unit leaf area). Maximum leaf transpiration rate estimated on the basis of $g_{\mathrm{s}}$ and vpd (disregarding aerodynamic components of conductance) reached $1.87 \pm 0.05 \mathrm{mmol} \mathrm{m}^{-2} \mathrm{~s}^{-1}$ at a vpd of ca. $1.6 \mathrm{kPa}$. Therefore, mean transpiration across all leaves was ca. eight times lower than maximum leaf transpiration of fully sun-exposed leaves. This discrepancy includes self-shading as well as aerodynamic effects, the latter a composit of leaf boundary layer phenomena plus canopy effects (lower effective vpd than assumed from midcanopy measurement).

During the experiment, sap flow was monitored with two Granier sensors installed about $50 \mathrm{~cm}$ above the cut end (Fig. 4a). SF was calculated from $\Delta \mathrm{T}$ using the standard calibration for trees:

$\left.\mathrm{SF}_{\text {Granier }}=0.714 \cdot\left(\left(\Delta T_{\max } / \Delta T\right)-1\right)^{1.231}\right) \cdot A$

(in $\mathrm{ml} \mathrm{min}^{-1}$, see Granier 1985), with the sap wood area $A$ of $14.6 \mathrm{~cm}^{2}$ in our case. With this equation, we underestimated water uptake by a factor of ca. 2 (Fig. 4b). Nevertheless, relative values of sap flow and potometer water consumption fitted highly significantly for both sensor couples installed $\left(r_{\text {adj }}^{2}=0.993\right.$ for sensor 1 and
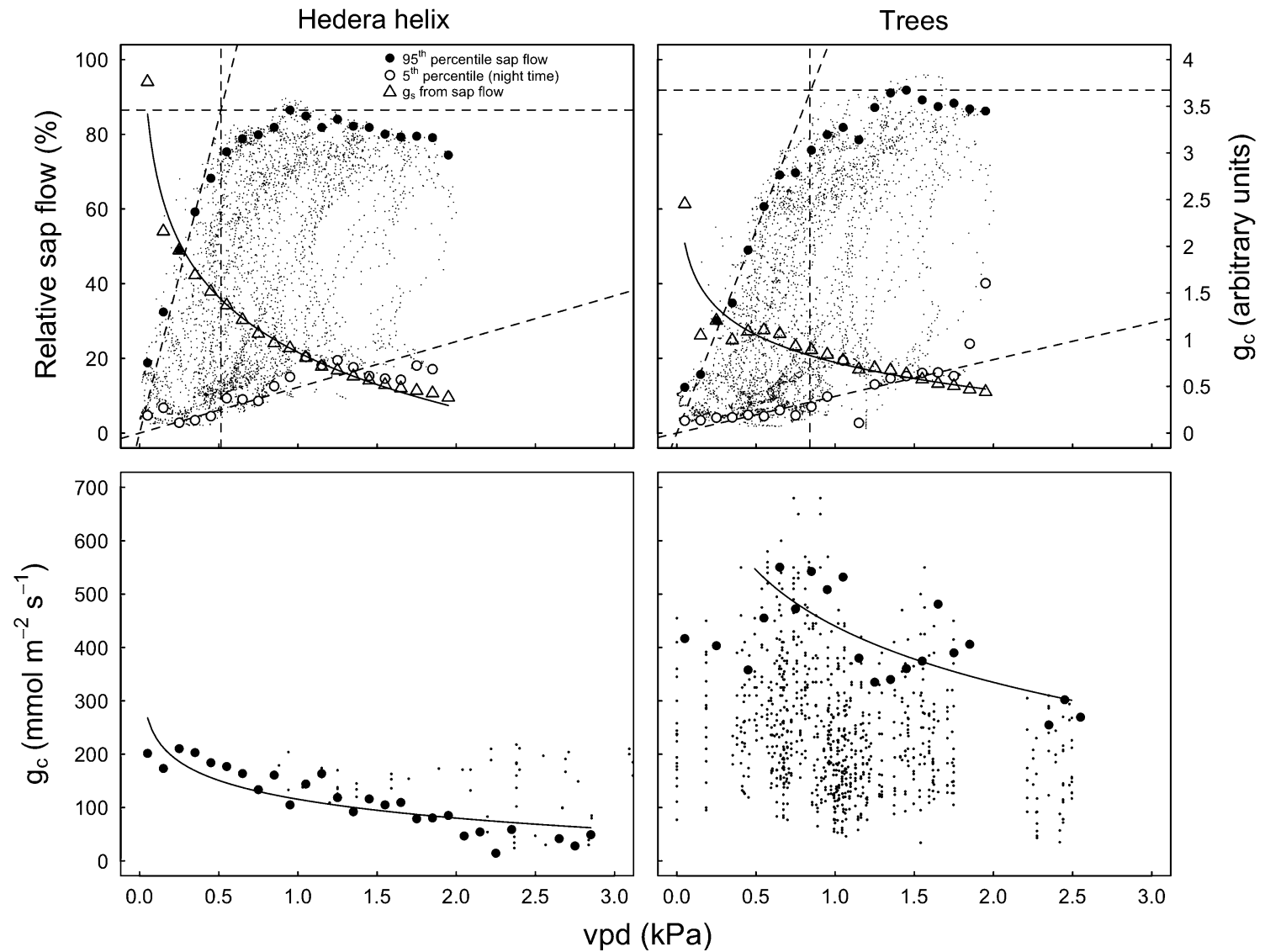

Fig. 2 Top panels mean sap flow (from 14 June to 8 August, relative to seasonal maximum, $n=6$ for ivy, $n=9$ for trees) to vapour pressure deficit (vpd). 95th percentiles for vpd (class width $0.1 \mathrm{kPa}$ ), marked as black points; solid lines show slope (linear regression through first 6 data points), maximum and the break point (intersection of slope and maximum). 5th percentiles of night-time data (between 11 p.m. and 4 a.m.) for vpd (class width $0.1 \mathrm{kPa}$ ) are marked as open circles; dashed lines show linear regressions. Triangles show $g_{c}$ (canopy conductance) estimated from sap flow, with a non-linear regression model fitted (see text). Bottom panels response of stomatal leaf conductance $\left(g_{\mathrm{s}}\right)$ to vpd, 95th percentiles (class width $0.1 \mathrm{kPa}$ ) are marked as black symbols, with a non-linear model fit (see text). Values of stomatal leaf conductance of trees are from Keel et al. (2007) 
Fig. 3 Response of 95th percentiles of mean sap flow (relative to seasonal maximum, $n=6$ ) to vapour pressure deficit (vpd, class width $0.1 \mathrm{kPa}$ ). Periods of 13 days before (early April, grey line) and after canopy closure (midMay, black line) are shown. Error bars represent one standard error
Fig. 4 Water consumption of adult ivy on a clear day in 2004 (points) and calculated sap flow measured with Granier-type sensors using three different models. Subpanels $\mathbf{b}-\mathbf{d}$ show the fit of those models (water consumption vs. calculated water flow based on sensors
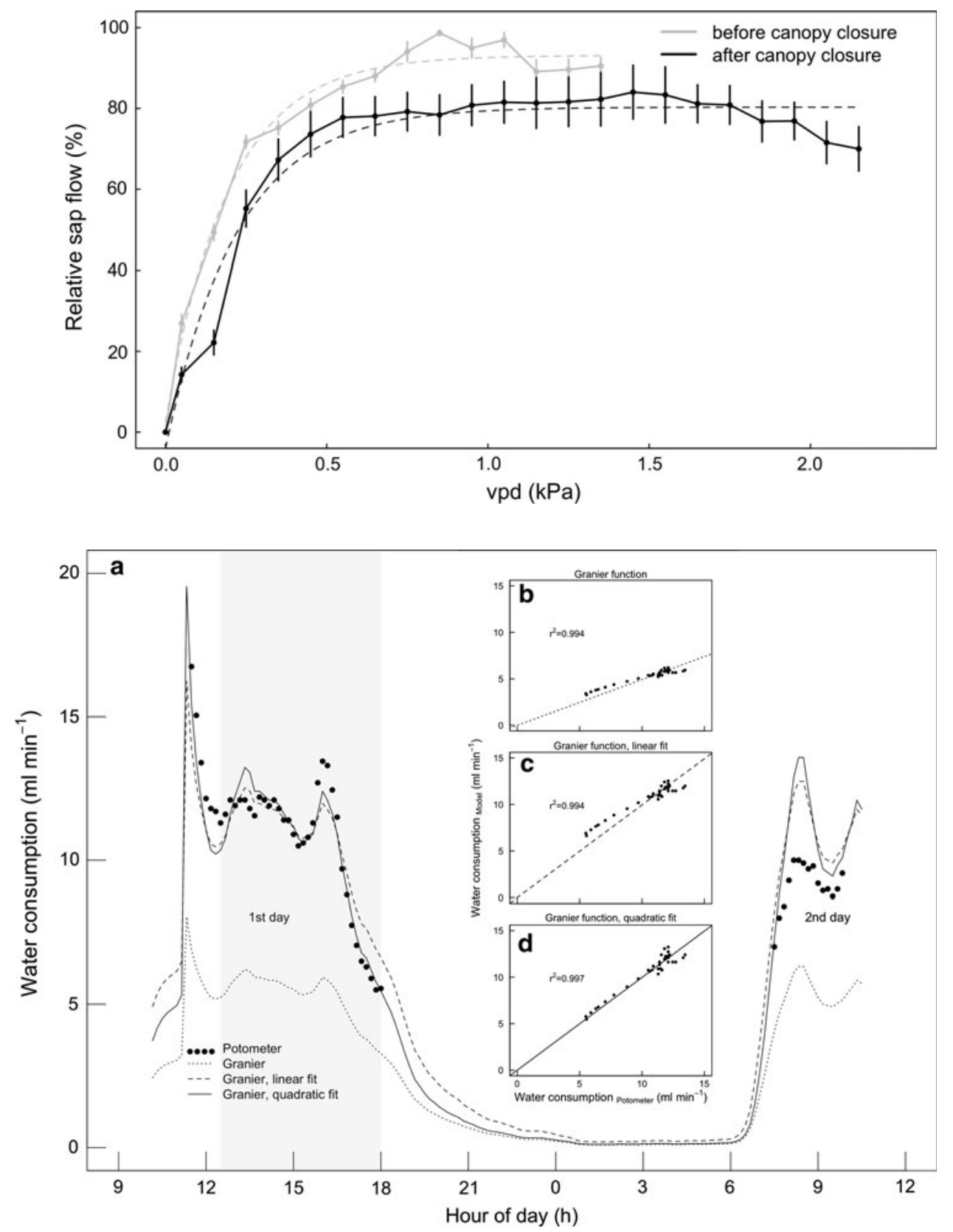

$r_{\mathrm{adj}}^{2}=0.995$ for sensor $2 ; P<0.001$ for both sensors). We adjusted Eq. 1 for estimating absolute flow rates in ivy with the best linear fit $\left(\mathrm{SF}=2.018 \mathrm{SF}_{\mathrm{Granier}}\right.$, Fig. 4c) and the best quadratic fit $\left(\mathrm{SF}=0.016 \mathrm{SF}_{\text {Granier }}^{2}+1.139 \mathrm{SF}_{\text {Granier }}\right.$, Fig. 4d) based on data obtained during the first day (ignoring the initial $30 \mathrm{~min}$ after cutting).

Night-time transpiration

Night-time sap flow of ivy was strongly vpd-dependent (Fig. 2 top left panel; linear regression through the 5th percentiles of night-time data, between $11 \mathrm{pm}$ and $4 \mathrm{am}$, for vpd classes of $0.1 \mathrm{kPa}, r_{\mathrm{adj}}^{2}=0.92$ ). During warm and dry summer nights when vpd exceeded $1 \mathrm{kPa}$, relative sap flow did not fall below $20 \%$ of the seasonal maximum. Hence, ivy loses substantial amounts of water at night during periods of high soil moisture. Night-time transpiration of trees was lower (ca. $10 \%$ of seasonal maximum at $1 \mathrm{kPa}$ ).

\section{Discussion}

This study for the first time presents a comprehensive data set on water relations of the most important European liana, Hedera helix. Our study suggests that (1) Hedera helix exerts a tight control over its water use, ensuring high 
leaf water potentials irrespective of climatic conditions (isohydric behaviour relative to their host trees). This control over plant water use is accomplished by an early down-regulation of leaf conductance in response to increasing vapour pressure deficit (and/or transpirational flow rate itself), which results in sap flow maxima reached at very low vpd $(0.5 \mathrm{kPa})$. (2) Canopy leafing of deciduous trees in spring strongly influences the water relations of climbing ivy, causing a considerable reduction of maximum sap flow in response to vapour pressure deficit. Ivy may strongly profit from mild days before canopy leafing causes strong light interception. (3) Granier sensors cannot be used for ivy applying the standard calibration for trees; instead, we suggest a specific model calibration for ivy.

Differences in predawn $\Psi$ at the different heights above ground were caused by differences in hydrostatic water potential only. Host trees showed similar predawn $\Psi$ at comparable soil water status in the previous year (Leuzinger et al. 2005). The faster reduction of diurnal leaf water potential in 23 compared with $12 \mathrm{~m}$ is probably related to significantly higher light intensities and thus stomatal conductance in the upper canopy. However, this could not be verified as the light regime was changing too rapidly and concurrent measurements of $\Psi$ and $g_{\mathrm{s}}$ were not possible from the crane gondola. Diurnal $\Psi$ at the same height was much lower in host trees $(<-2 \mathrm{MPa}$ at ample soil moisture, Leuzinger et al. 2005), and stomatal downregulation occurred later, which points to a comparatively anisohydric water use as opposed to the more isohydric behaviour by ivy. This difference between ivy and its host trees is further evidenced in Fig. 2, where both a steeper initial slope and an earlier break point in the relative SF-vpd plot are apparent for ivy compared with its host trees. A possible explanation for this is the strong atmospheric coupling of the host trees, while this was much less the case for Hedera helix with its dense canopies. The $g_{\mathrm{c}}-\mathrm{vpd}$ model fit is not representative in absolute terms as the $g_{\mathrm{c}}$ data are an estimate based on relative sap flow, not considering the unknown sap wood-to-leaf area ratio and storage. However, $e^{\mathrm{b} / \mathrm{m}}$, the hypothetical vpd threshold of complete stomatal closure, ranks among the very lowest in a comparison of several tree species reported by Oren et al. (1999), suggesting a particularly high stomatal sensitivity as is known for other broad-leaved evergreen species from humid environments (e.g. Körner and Bannister 1985). The model fit to the $g_{\mathrm{s}}$ data (Fig. 2, bottom panels) yields higher $e^{\mathrm{b} / \mathrm{m}}$ values for both ivy and trees (consistent with data summarised in Oren et al. 1999), but ivy remains ca. 50\% lower than trees, again emphasising its strong stomatal sensitivity. Because of the large xylem vessels of lianas (Ewers et al. 1991), cavitation events should have a relatively large impact on conductivity of ivy stems. The highly conservative flow control may have evolved as an adaptation to the high vulnerability of ivy to cavitation. The benefit of the large vessels may be the low resistance to sap flow, which allows high transpiration rates at low vpd conditions and thus optimal nutrient and carbon acquisition during winter months (Fischer and Feller 1994). This view is supported by the highly consistent water consumption throughout bad weather conditions with low vpd $(<0.5 \mathrm{kPa})$ and low light (peaks of $<500 \mu \mathrm{mol}$ photons $\mathrm{m}^{-2} \mathrm{~s}^{-1}$ ).

The reduction in relative maximum sap flow following canopy closure in spring was most likely due to increased shading from trees and the altered canopy boundary layer property (less wind, Fig. 3). The reduction of the initial slope of the relative SF-vpd curve following bud break is probably also due to reduced light availability and less atmospheric coupling. The time window before canopy closure could represent a temporal niche during which ivy plants gain substantial advantage in carbon assimilation over their host plants.

To estimate the increasing advantage ivy may have over its host trees with warmer winter temperatures, we propose a (coarse) estimate for $\mathrm{C}$-assimilation using sap flow as a proxy. The argument is based on the fact that ultimately, sap flow (transpiration) is intimately coupled to C-assimilation (Körner et al. 1979, see their Fig. 3) and that photosynthetic proteins are active during warm spells (Fischer and Feller 1994). We therefore assume that C-assimilation is approximately proportional to sap flow throughout the year as long as temperature and light are non-limiting. Using a simple temperature-dependence (growth is zero at $T \leq 6^{\circ} \mathrm{C}$ and increases linearly until $T=20^{\circ} \mathrm{C}$, no temperature limitation at $>20^{\circ}$ ), we estimated $\mathrm{C}$-assimilation for pre- and post leafing SF-vpd curves (mean growing season length 202 days, Asshoff et al. 2006), with vpd data from a 109-year climate data series nearby (Tank et al. 2002). Because ivy achieves $90 \%$ of maximum photosynthesis at $360 \mu \mathrm{mol}$ photons $\mathrm{m}^{-2} \mathrm{~s}^{-1}$ (Carter and Teramura 1988), and because light is strongly correlated with both vpd and $T$, we did not include explicit light limitation. Our estimation of the fraction of carbon assimilated during winter shows an almost 50\% increase from 1980 to 2009 (6\% in 1980 vs. $10 \%$ in 2010, Fig. 5). Therefore, if carbon assimilation in summer remained constant, and under the assumption that growth in the subcanopy is carbon limited, ivy showed an increase in carbon gain over the past 30 years. This may explain the increased diameter growth in years with warm winters reported by Heuzé et al. (2009). With winter temperatures expected to rise between 1.5 and $5^{\circ} \mathrm{C}$ compared to 1990 in the studied area (OcCC 2008), this trend could continue. A lengthening of the growing season may slightly counteract this trend, but most deciduous host trees' phenology at this site is not solely controlled by temperature but exhibits photoperiod control, in particular beech (Körner and Basler 2010). 
Fig. 5 Estimate of the fraction of carbon assimilated in winter versus summer based on sap flow using a 109-year climate data set from a nearby site. The smooth line is a spline function (function 'smooth.spline', smoothing parameter $0.7, \mathrm{R}$ Development Core Team 2009)

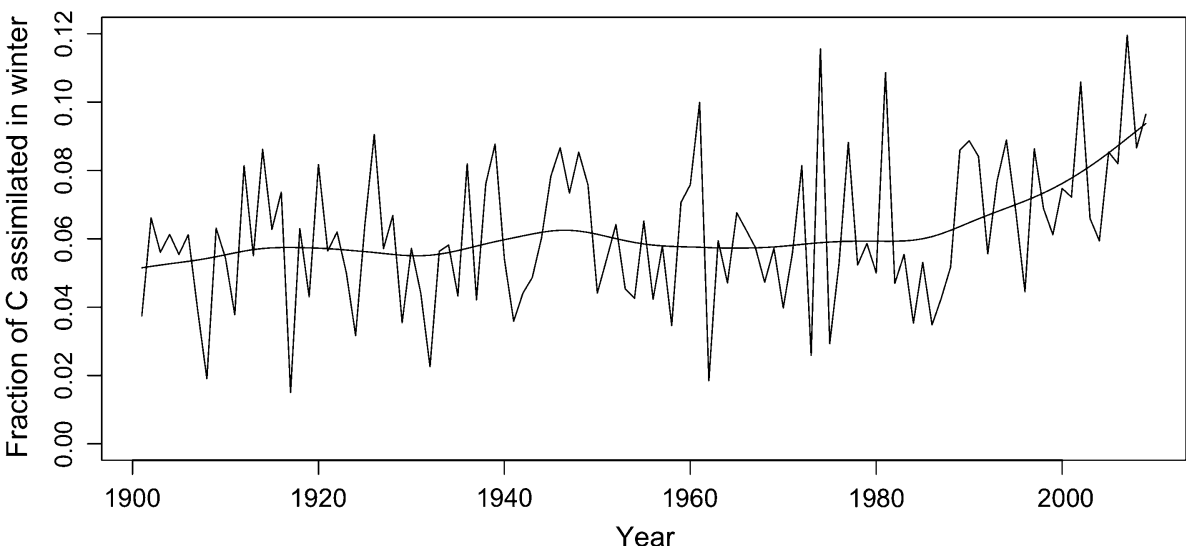

Sap flow was calculated using the standard calibration factor for trees (Granier 1985). The underestimation of sap flow by a factor of ca. 2, however was surprisingly high. The reason for this could be the relatively large xylem vessels of ivy. Steppe et al. (2010) showed that this can lead to an underestimation of sap flow with the constant heat sensors. We propose to use a specific model for ivy by replacing the standard sap flow density calibration factor of 0.714 in Eq. 1 by an adjusted factor of 1.441. Our results confirm the often encountered difficulty to infer absolute flux rates from sap flow signals (Leuzinger and Körner 2007), particularly in ring porous species (Bush et al. 2010). Because relative sap flow correlated well in all three models in Fig. 4, an alternative may be to assume a reasonable seasonal maximum transpiration rate against which sap flow data can be calibrated, particularly under field conditions and when little information on the sap wood area is available. The average sap flow density measured for ivy (volume of water per unit area per second, $1.5 \times 10^{-4} \mathrm{~m}^{3} \mathrm{~m}^{-2} \mathrm{~s}^{-1}$ ) was higher by an order of magnitude than sap flow densities estimated for trees at the same site (ca. $2 \times 10^{-4} \mathrm{~m}^{3} \mathrm{~m}^{-2} \mathrm{~s}^{-1}$, Cech et al. 2003). The missing root resistance in the potometer experiment probably only accounts for a small fraction of this large difference and ivy certainly has very high sap flow density.

Night-time sap flow was in the upper range (up to $20 \%$ of seasonal maximum) of values reported for other plants (Caird et al. 2007). In our case, night-time sap flow could have been caused by (1) actual night-time transpiration, (2) compensation of phloem basipetal flux or (3) sap flow induced by the refilling of stem and leaf reservoirs. Nighttime transpiration alone is an insufficient explanation because sap flow was also observed during rainy nights when vpd was close to $0 \mathrm{kPa}$ (data not shown). The potometer experiment showed a maximum transpiration rate of $13.5 \mathrm{ml} \mathrm{min}^{-1}$ for a total leaf mass of about $13 \mathrm{~kg}$. To refill $10 \%$ of the total water content of leaves (at $85 \%$ water content) during the night, maximum sap flow rates during almost $1.5 \mathrm{~h}$ would have been required. Therefore, refilling of plant water reserves likely contributed to the flux at night, but a combination of all three mentioned phenomena is most likely. Night-time transpiration may be advantageous for nutrient acquisition (Tanner and Beevers 2001), but this is not true for all species (Christman et al. 2009) and the phenomenon awaits general clarification (Cramer et al. 2009).

In conclusion, we argue that Hedera helix has evolved a very conservative, in tendency isohydric water use strategy that is strongly adapted to optimally use light before bud break of surrounding trees and after leaf fall in autumn. Its high transpiration rates at low vpd are possible through minimising stem resistance at the cost of early stomatal downregulation to avoid cavitation. With winters getting milder, we expect ivy to firstly suffer less from severe frosts. Second, ivy may grow more vigorously as a larger proportion of carbon may be assimilated during warming winters (at constant summer assimilation rates) while its host trees are dormant, still not accounting for $\mathrm{CO}_{2}$-fertilisation effects as evidenced by Zotz et al. (2006). Both winter-time warming and $\mathrm{CO}_{2}$-fertilisation in low light conditions could speed up temperate forest succession due to increased presence of ivy.

Acknowledgments We would like to thank E. Amstutz and O. Bignuccolo for crane operation and logistic help. Further, we thank S. Keel for providing us with stomatal conductance data of host trees. This work is part of a Master's Thesis conducted by A. H. Funding came from the Swiss National Science Foundation projects 3100-059769.99 and 5005-65755 (NCCR Climate) granted to C. K. The Swiss Canopy Crane is funded by the Swiss Agency for the Environment, Forest and Landscape. Funding for S. L. partially came from the FP7 project 'ACQWA'.

\section{References}

Andergassen S, Bauer H (2002) Frost hardiness in the juvenile and adult life phase of ivy (Hedera helix L.). Plant Ecol 161:207-213

Asshoff R, Zotz G, Körner C (2006) Growth and phenology of mature temperate forest trees in elevated $\mathrm{CO}_{2}$. Glob Change Biol $12: 848-861$ 
Biggerstaff MS, Beck CW (2007) Effects of method of English ivy removal and seed addition on regeneration of vegetation in a southeastern piedmont forest. Am Midl Nat 158:206-220

Bush SE, Hultine KR, Sperry JS, Ehleringer JR (2010) Calibration of thermal dissipation sap flow probes for ring- and diffuse-porous trees. Tree Physiol 30:1545-1554

Caird MA, Richards JH, Donovan LA (2007) Nighttime stomatal conductance and transpiration in $\mathrm{C}_{3}$ and $\mathrm{C}_{4}$ plants. Plant Physiol 143:4-10

Carter GA, Teramura AH (1988) Vine photosynthesis and relationships to climbing mechanics in a forest understory. Am J Bot 75:1011-1018

Cech PG, Pepin S, Körner C (2003) Elevated $\mathrm{CO}_{2}$ reduces sap flux in mature deciduous forest trees. Oecologia 137:258-268

Christman MA, Donovan LA, Richards JH (2009) Magnitude of nighttime transpiration does not affect plant growth or nutrition in well-watered Arabidopsis. Physiol Plant 135:264-273

Clark DB, Clark DA (1990) Distribution and effects on tree growth of lianas and woody hemiepiphytes in a Costa Rican tropical wet forest. J Trop Ecol 6:321-331

Cramer MD, Hawkins HJ, Verboom GA (2009) The importance of nutrient regulation of plant water flux. Oecologia 161:15-24

Elias P (1979) Contribution to the eco physiological study of the water relations of forest shrubs. Preslia 51:77-90

Ewers FW, Fisher JB, Fichtner K (1991) Water flux and xylem structure in vines. In: Putz FE, Mooney HA (eds) Biology of vines. Cambridge University Press, Cambridge, pp 127-160

Fischer A, Feller U (1994) Seasonal changes in the pattern of assimilatory enzymes and the proteolytic activities in leaves of juvenile ivy. Ann Bot 74:389-396

Granados J, Körner C (2002) In deep shade, elevated $\mathrm{CO}_{2}$ increases the vigor of tropical climbing plants. Glob Change Biol 8:1109-1117

Granier A (1985) A new method of sap flow measurement in tree stems. Ann Sci For 42:193-200

Hättenschwiler S, Körner C (2000) Tree seedling responses to in situ $\mathrm{CO}_{2}$-enrichment differ among species and depend on understorey light availability. Glob Change Biol 6:213-226

Hättenschwiler S, Körner C (2003) Does elevated $\mathrm{CO}_{2}$ facilitate naturalization of the non-indigenous Prunus laurocerasus in Swiss temperate forests? Funct Ecol 17:778-785

Heuzé P, Dupouey J-L, Schnitzler A (2009) Radial growth response of Hedera helix to hydrological changes and climatic variability in the Rhine floodplain. River Res Appl 25:393-404

Iversen J (1944) Viscum, Hedera and Ilex as climate indicators. Eologiska Föreningens Förhandlingar 66:463-483

Keel SG, Pepin S, Leuzinger S, Körner C (2007) Stomatal conductance in mature deciduous forest trees exposed to elevated $\mathrm{CO}_{2}$. Trees 21:151-159

Körner C (2004) Through enhanced tree dynamics carbon dioxide enrichment may cause tropical forests to lose carbon. Philos Trans Roy Soc B 359:493-498

Körner C, Bannister P (1985) Stomatal responses to humidity in Northofagus menziesii. N Z J Bot 23:425-429

Körner C, Basler D (2010) Phenology under global warming. Science 327:1461-1462

Körner C, Scheel A, Bauer H (1979) Maximum leaf diffusive conductance in vascular plants. Photosynthetica 13:45-82

Leuzinger S, Körner C (2007) Water savings in mature deciduous forest trees under elevated $\mathrm{CO}_{2}$. Glob Change Biol 13:24982508
Leuzinger S, Zotz G, Asshoff R, Körner C (2005) Responses of deciduous forest trees to severe drought in Central Europe. Tree Physiol 25:641-650

Metcalfe DJ (2005) Hedera helix (L.), biology of the British Isles. J Ecol 93:632-648

Mitchell AF (1975) Three forest climbers. Forestry Commission Forest Record 102. Her Majesty's Stationery Office, London

Mohan JE, Ziska LH, Schlesinger WH, Thomas RB, Sicher RC, George K, Clark JS (2006) Biomass and toxicity responses of poison ivy (Toxicodendron radicans) to elevated atmospheric $\mathrm{CO}_{2}$. Proc Natl Acad Sci USA 103:9086-9089

Monteith JL (1995) A reinterpretation of stomatal response to humidity. Plant Cell Environ 18:357-364

OcCC (2008) Das Klima ändert sich-was nun? Der neue UN-Klimabericht (IPCC 2007) und die wichtigsten Ergebnisse aus Sicht der Schweiz. OcCC - Organe consultatif sur les changements climatiques, Bern. ISBN 978-3-907630-33-4

Oren R, Sperry JS, Katul GG, Ewers BE, Pataki DE, Phillips N, Schäfer KVR (1999) Survey and synthesis of intra- and interspecific responses of canopy stomatal conductance to vapour pressure deficit. Plant Cell Environ 22:1515-1526

Parker J (1962) Relationships among cold hardiness, watersoluble protein, anthocyanins and free sugars in Hedera helix L. Plant Physiol 37:809-813

Pataki DA, Oren R, Tissue DT (1998) Elevated carbon dioxide does not affect average canopy stomatal conductance of Pinus taeda L. Oecologia 117:47-52

Putz FE (1984) The natural history of lianas on Barro Colorado Island, Panama. Ecology 65:1713-1724

Putz FE, Holbrook M (1991) Biomechanical studies of vines. In: Putz FE, Mooney HA (eds) Biology of vines. Cambridge University Press, Cambridge, pp 73-98

R Development Core Team (2009) R: a language and environment for statistical computing. R Foundation for Statistical Computing, Vienna

Ringold PL, Magee TK, Peck DV (2008) Twelve invasive plant taxa in US western riparian ecosystems. J N Am Benthol Soc 27:949-966

Schnitzer SA, Bongers F (2002) The ecology of lianas and their role in forests. Trends Ecol Evol 17:223-230

Schnitzler A, Heuzé P (2006) Ivy (Hedera helix L.) dynamics in riverine forests: effects of river regulation and forest disturbance. For Ecol Manag 236:12-17

Steppe K, De Pauw DJW, Doody TM, Teskey RO (2010) A comparison of sap flux density using thermal dissipation, heat pulse velocity and heat field deformation methods. Agric For Meteorol 150:1046-1056

Tank AMGK, Wijngaard JB, Konnen GP et al (2002) Daily dataset of 20th-century surface air temperature and precipitation series for the European Climate Assessment. Int J Climatol 22:1441-1453

Tanner W, Beevers H (2001) Transpiration, a prerequisite for longdistance transport of minerals in plants? Proc Natl Acad Sci USA 98:9443-9447

Zhu SD, Cao KF (2010) Contrasting cost-benefit strategy between lianas and trees in a tropical seasonal rain forest in southwestern China. Oecologia 163:591-599

Zotz G, Cueni N, Körner C (2006) In situ growth stimulation of a temperate zone liana (Hedera helix) in elevated $\mathrm{CO}_{2}$. Funct Ecol 20:763-769 